\title{
Effect of Zinc and Boron on Growth, Yield, Bulb quality and Nutrient uptake of Onion (Allium cepa L.) cv Bhima Super under Mid-Central Table Land Zone of Odisha, India
}

\author{
M. Prusty ${ }^{1 *}$, N. Mishra ${ }^{2}$, S. Samal ${ }^{3}$ and D. S. Kar ${ }^{4}$ \\ ${ }^{1}$ Department of Soil Science, ${ }^{3}$ Department of Horticulture, Regional Research and \\ Technology Transfer Station, Mahisapat, Dhenkanal, Odisha University of Agriculture and \\ Technology, Bhubaneswar,751003, Odisha, India, \\ ${ }^{2}$ Department of Horticulture, Regional Research and Technology Transfer Station, \\ Judia farm, Keonjhar, Odisha University of Agriculture and Technology, \\ Bhubaneswar-751003, Odisha, India, \\ ${ }^{4}$ Department of Horticulture, ICAR-Krishi Bigyan Kendra, Dhenkanal, Odisha University of \\ Agriculture and Technology, Bhubaneswar, 751003, Odisha, India \\ *Corresponding author
}

\section{A B S T R A C T}

\begin{tabular}{|l|}
\hline Ke y w o r d s \\
Zinc, boron, onion, \\
growth, yield, \\
uptake
\end{tabular}

\begin{abstract}
Present study was conducted at the Experimental Farm of the Regional Research and Technology Transfer Station, Mahisapat of Dhenkanal district which is situated in Mid Central Table Land zone of Odisha during Rabi 2016-17 and Rabi 2017-18 with six treatments which were arranged in Randomized Block Design with four replications as follows: $\mathrm{T}_{1^{-}}$Soil Test Based Fertilizer Recommendation (STBFR), $\mathrm{T}_{2^{-}}$ STBFR+ Soil application of Boron @ $1.0 \mathrm{~kg} / \mathrm{ha}, \mathrm{T}_{3}-\mathrm{STBFR}+$ soil application of Boron @ $0.5 \mathrm{~kg} / \mathrm{ha}+$ Foliar spray of Borax @ $0.2 \%$ two times at $30 \& 45$ DAP , T 4 - STBFR + Soil application of Zinc @5 $\mathrm{kg} / \mathrm{ha}, \mathrm{T}_{5}-\mathrm{STBFR}+$ Soil application of Zinc @ $2.5 \mathrm{~kg} / \mathrm{ha}+$ Foliar spray of $\mathrm{ZnSO}_{4} @ 0.5 \%$ two times $30 \& 45$ DAP, T 6 - STBFR+ Soil application of Boron@1 kg/ha \&Zinc @ $5 \mathrm{~kg} / \mathrm{ha}$. Obtained results indicated that application of micronutrients like Boron and Zinc to onion crop have significant impact on production of better bulb quality in terms of TSS and also provided better yield and nutrient uptake. Among all the treatment schedule, it was observed that the treatment schedule, $\mathrm{T}_{6}$ i.e., STBFR+ Soil application of Boron @ $1 \mathrm{~kg} / \mathrm{ha}$ \&Zinc @ $5 \mathrm{~kg} / \mathrm{ha}$ significantly recorded highest bulb diameter $(6.79 \mathrm{~cm})$, bulb weight $(72.57 \mathrm{~g})$ resulted highest bulb yield $(243.0 \mathrm{q} / \mathrm{ha})$. The available nutrient content in bulb $(1.58 \%, 0.5 \%$ and $1.59 \%$ of $\mathrm{N}, \mathrm{P}$ and $\mathrm{K}$ respectively) and nutrient uptake in bulb $(141.45 \mathrm{~kg} / \mathrm{ha}, 11.27 \mathrm{~kg} / \mathrm{ha}, 112.00 \mathrm{~kg} / \mathrm{ha}$ of $\mathrm{N}, \mathrm{P}, \mathrm{K}$ respectively) are also found to be highest in $\mathrm{T}_{6}$ which was significantly higher than rest other treatments.
\end{abstract}

\section{Introduction}

Onion (Allium cepa L.), the "Queen of Kitchen" is one of the most important commercial bulbous vegetable crop extensively cultivated not only in India but also in the world. Onion is the most widely cultivated species of the genus Allium. It belongs to family Alliaceae. Onion bulb is a rich source of minerals like phosphorus and calcium. It also contains protein and vitamin $\mathrm{C}$, quercetin and flavonoids. The most important chemical content in onion is Allyl propyl disulphide which is responsible for its 
pungency. It is known for its unique flavour thus it is used in daily diet. The total area under production of onion in India during 2016-2017 was 1270.4 thousand ha with 21563.9 thousand MT production and 17.0 MT/ha productivity (Anonymous, 2017) which is very low. Productivity could be increased by use of suitable varieties, balanced nutrition, optimum water management as well as need based plant protection measures. Among the many constraints of low productivity in onion, imbalanced nutrition is the main limiting factor.

In addition to nitrogen, phosphorus, potassium micronutrient has a great role in the fertilization programme to achieve higher and sustainable yields (Singh \& Tiwari, 1996). Although the requirement of a micronutrient is small compared to a macronutrient, nevertheless micronutrient deficiency can limit the crop growth and production. Micronutrients have a great role in the fertilizer program to achieve higher and sustainable crop yields (Fouda, 2017).Even though, micronutrients are needed by the plants in a minor quantity and present in plant tissue in quantities measured in parts per million but it is involved in a wide variety of metabolic processes and cellular functions within the plants. Also, they work as a coenzyme for a large number of enzymes. In addition, they play an essential role in improving quality, and highly required for better plant growth and yield of many crops (Ballabh and Rana, 2012). Deficiency of micronutrients during the last three decades has grown both in magnitude and extent. This has become a major constraint to production $\&$ productivity of onion.

Zinc is a micronutrient which is required for plant growth and development relatively in small amount. The functional role of $\mathrm{Zn}$ include auxin metabolism, influence on the activity of dehydrogenase and carbonic an hydrate enzymes, synthesis of cytochrome and stabilization of ribosomal fractions (Tisdale et al., 1984). Zinc also plays an imp role in chlorophyll and grain formation. Application of Zinc increased the growth and yield of onion (Phor et al., 1995).Boron is the micronutrient required for development of growing points, movement of sugars and starches to developing parts, movement of nutrient elements within the plant, formation of plant hormones affecting growth, root growth and health of fleshy roots, flower and fruit set and quality and flavour of vegetables (Vitosh et al., 2001). Although it is quickly taken up from the soil, it is relatively immobile in the plant. Application of boron increases bulb size, weight per bulb and yield of onion (Smiriti et al., 2002).Foliar application of micronutrients could be beneficial as to prevent nutrient deficiency and to avoid soil problems that affect their availability (Fouda, 2017).Keeping this in a view, a field experiment was conducted at Regional Research and Technology Transfer Station, Mahisapat, Dhenkanal "To study the Effect of Zinc and Boron on Growth, Yield, Bulb quality and Nutrient uptake of Onion."

\section{Materials and Methods}

The field experiment was conducted at Regional Research and Technology Transfer Station, Mahisapat of Dhenkanal district which is situated in Mid Central Table Land zone of Odisha in rabi season during the year 2016-17 and 2017-18. The farm is located in the geographical parallels between $20^{\circ}-3$ 'and $21^{\circ}-16^{\prime}$ North latitudes and $84^{\circ}$ and $86^{\circ}-6^{\prime}$ East longitude. The important soil groups of the zone are alluvial (Entisol), Black (Vertisol), red-laterite (Alfisol) and lateritic (Oxisol). The soil of experimental site was red, sandy loam in texture $\&$ acidic in reaction $\left(\mathrm{P}^{\mathrm{H}}=5.58\right)$ with available $\mathrm{N}, \mathrm{P}, \mathrm{K}, \mathrm{B}$ and $\mathrm{Zn}$ of $250 \mathrm{~kg} / \mathrm{ha}, 16 \mathrm{~kg} / \mathrm{ha}, 190 \mathrm{~kg} / \mathrm{ha}, 0.4 \mathrm{mg} / \mathrm{kg}$ and 
$0.3 \mathrm{mg} / \mathrm{kg}$ respectively. The field trial was laid out by adopting RBD design with four replications and six treatments and the treatments are $\mathrm{T}_{1}$ - Soil Test Based Fertilizer Recommendation (STBFR), $\mathrm{T}_{2}-\mathrm{STBFR}+$ Soil application of Boron @ $1.0 \mathrm{~kg} / \mathrm{ha}, \mathrm{T}_{3}-\mathrm{STBFR}$ + soil application of Boron @0.5 kg/ha + Foliar spray of Borax @ $0.2 \%$ two times at $30 \& 45$ DAP , T 4 - STBFR + Soil application of Zinc @5 kg/ha, $\mathrm{T}_{5^{-}}$STBFR+ Soil application of Zinc @ $2.5 \mathrm{~kg} / \mathrm{ha}+$ Foliar spray of $\mathrm{ZnSO}_{4} @ 0.5 \%$ two times 30 \&45 DAP, T $6^{-}$ STBFR+ Soil application of Boron @ 1 kg/ha \&Zinc @ 5 kg/ha. Onion seed var. Bhima super was sown in nursery bed prepared by mixing FYM @20 kg and NPK mixture @ 20 $\mathrm{g} / \mathrm{bed}$.

About 55 days seedlings of $10-15 \mathrm{~cm}$ height were planted in the main field at a spacing of $15 \times 10 \mathrm{~cm}$. Soil test based fertilizer Recommendation for the crop was 140:50:60 NPK kg/ha along with FYM @ 5 t/ha applied uniformly in all treatments. The sources of $\mathrm{N}, \mathrm{P}, \mathrm{K}, \mathrm{Zn}$ \& $\mathrm{B}$ for the present study were Urea, DAP ,MOP ,Zinc sulphate and Borax respectively. The whole FYM was applied 10 days prior to planting. The full dose of $\mathrm{P}, \mathrm{K} \&$ half dose of $\mathrm{N}$ was applied at the time of planting of seedlings. The remaining $50 \%$ of $\mathrm{N}$ was applied in two equal splits at 30 and 45 days after planting of onion seedlings. Micronutrients were applied as per the treatment schedule.

Data on growth parameters (plant height) was taken just before harvesting and the yield parameters such as bulb diameter $(\mathrm{cm})$, fresh weight of bulb (g) gross yield per plot $(\mathrm{kg})$ and hectare were recorded from the sample plants just after harvesting. Ten plants were randomly selected for this purpose from each plot in such a way so that border effect could be avoided. The composite soil samples were collected treatment wise after harvest and analysed as per the standard procedure.
The plant samples were analysed for the major nutrients by the standard methods (Chopra et al., 1978). Bulb nutrient content for NPK were determined from powdered bulb samples by using micro Kjeldahl's, spectrophotometer and flame photometer respectively (Jackson, 1973). Total soluble solids (TSS) were determined by using refractometer and expressed in degree brix. The statistical analysis was done as per the procedure given by Gomez and Gomez, 1984.

\section{Results and Discussion}

\section{Effect on plant height}

Plant height in onion differed significantly due to different micronutrient treatments. Vegetative growth in onion significantly improved due to different micronutrient treatments. Application of STBFR+ Soil application of Boron @1 kg/ha \&Zinc @5 $\mathrm{kg} /$ ha resulted the highest plant height $(52.89$ $\mathrm{cm}$ ) and was significantly superior to rest other treatments. Pramanik et al., (2018) noticed increased in plant height by application of micronutrients.

The increase in growth parameters of onion with progressive increase in the application of boron might be due to their role in cell division, meristematic activity of plant tissue and expansion of cell (Patil et al., 2009). The favourable effect of boron on plant growth might also be due to its role in physiological processes such as carbohydrate and protein metabolism and cellular function within the plant. Since boron is mainly involved in the hormone development and stimulation or inhibition of specific metabolism pathways (Waqar et al., 2009).

\section{Effect on yield attributes}

Yield attributing characters like Bulb diameter was $4.27 \mathrm{~cm}$ in the treatment where 
crop received only STBFR $\left(\mathrm{T}_{1}\right)$ which was increased to $6.19 \mathrm{~cm}$ and $6.79 \mathrm{~cm}$ in $\mathrm{T}_{5}$ (STBFR+ Soil application of Zinc @ $2.5 \mathrm{~kg} / \mathrm{ha}$ +Foliar spray of $\mathrm{ZnSO}_{4} @ 0.5 \%$ two times 30 \&45 DAP) and $\mathrm{T}_{6}$ (STBFR+ Soil application of Boron @1 kg/ha \&Zinc @5 kg/ha) respectively. This may be due to boron and zinc enhances the enzyme activity which in turn triggers the physiological process like protein and carbohydrate metabolism in plants. This in turn increases the diameter of the onion. These results were in conformity with Alam et al., (2010) and Manna (2013)

Similarly, the highest average bulb weight of $72.57 \mathrm{~g}$ was found in $\mathrm{T}_{6}$ which is significantly higher than that of $\mathrm{T}_{5}$ havingbulb weight of 69.2g(Table -1). Tariq et al., (2018) also reported significant increase of growth parameters due to application of B and Zn.

The increase in growth parameters with the application of zinc might be due to their role in the cell division and other physiological processes like photosynthesis, nitrogen metabolism etc. Zinc is also a part of several other enzymes such as superoxide dismutase and catalase, which prevents oxidative stress in plant cells.

In addition to above zinc plays an important role in production of tryptophan which in turn is precursor of auxin, an essential growth hormone for plant growth. The results are in conformity with Gamili et al., (2000); Verma et al., (1995) in onion; Tiwari et al., (2003) in garlic .

This may be due to zinc and boron play an essential role in plant growth through the biosynthesis of endogenous hormones which is responsible for promotion of plant growth, role in cell division, meristematic activity of plant tissue and expansions of cells. This in turn results in highest fresh weight of the bulb. The results are similar to Hansch and Mendel, 2009and Patil et al., (2008).

\section{Effect on yield}

The yield of the bulb was varied from 180.5 $\mathrm{q} /$ ha to $243.0 \mathrm{q} / \mathrm{ha}$ among the treatments. The highest yield was found in $\mathrm{T}_{6}(243.0 \mathrm{q} / \mathrm{ha})$ followed by $\mathrm{T}_{5}(234.5 \mathrm{q} / \mathrm{ha})$. The lowest yield of $180.5 \mathrm{q} /$ ha was found in $\mathrm{T}_{1}$ where only Soil test fertilizer dose was applied. The results obtained by Khan et al., (2007) was also in close conformity in this regard. The improvement in growth and yield attributes might have led to higher total yield in onion. These results confirm the findings of Manna (2013) who observed improvement in growth and bulb yield of onion due to foliar nutrition of zinc and boron. Higher photosynthesis accumulation in the bulb would ensure higher individual bulb weight, bulb diameter which leads to higher yield. There was $34.62 \%$ increase in yield in $\mathrm{T}_{6}$ than that of $\mathrm{T}_{1}$. This may be due to boron, as it has been considered as the essential component for cell division which is very necessary for the growth and development of the plant. Moreover, boron might have played unique role in participating excess cations, maintenance of conducting tissues with regulatory effect of on other elements. This in turn increases the yield of the onion. These results are in close agreement with those of Alam et al., 2010, Ballabh et al., (2013).

\section{Effect on total soluble solid ( $\mathrm{TSS}^{\mathbf{0}} \mathrm{Brix}$ )}

The Total Soluble Solids (Table -1) of harvested bulbs varied from $9.72^{\circ}$ Brix to $13.58{ }^{0}$ Brix in different treatments. Significantly highest TSS $13.57^{\circ}$ Brix was found in $\mathrm{T}_{6}$ (STBFR+ Soil application of Boron@1 kg/ha \&Zinc@5 kg/ha )which was at par with $\mathrm{T}_{5}$ (STBFR+ Soil application of Zinc@2.5 kg/ha +Foliar spray of ZnSO4@0.5\% two times 30 \&45 DAP) and the lowest TSS was found in $\mathrm{T}_{1}$ (STBFR ). The beneficial effect of zinc on onion quality might be due to its involvement in auxin 
metabolism in plants (Alam et al., 2010).However, all the micronutrient treatments were found significantly superior over $\mathrm{T}_{1}$ (STBFR only).The improvement in TSS content onion bulbs with application of micronutrients might be attributed to enhanced metabolic processes involved in biosynthesis of total soluble solid, such as carbohydrates organic acid, amino acid and other inorganic constituents (Acharya et al., 2015). Lal and Maurya, 1981 also stated that increased carbohydrates production during the process of photosynthesis and both zinc and boron play a vital role in photosynthetic activity of plant. The present results also corroborate with those of Trivedi and Dhumal (2013), Manna and Maity (2016) and Aske et al., (2017) in onion.

\section{Effect on available nutrient content in the} bulb

The highest Available nitrogen, phosphorus and potassium content in the bulb were $1.58 \%, 0.51 \%$ and $1.59 \%$ in $\mathrm{T}_{6}$ followed by $1.49 \%, 0.43 \%$ and $1.51 \%$ in $\mathrm{T}_{5}$ (Table.2).The lowest NPK content was found in $\mathrm{T}_{1}$ (STBFR).The highest NPK content in the bulb was found in $\mathrm{T}_{6}$ due to higher assimilation of nutrients in that treatment .
Effect on available nutrients in soil after harvest of the crop

The highest available nitrogen, phosphorus and potassium content after harvest of the crop were found in $\mathrm{T}_{1}(242.88,15.15$ and $188.65 \mathrm{~kg} \mathrm{ha}^{-1}$ respectively) and decreased in other treatments due to soil and foliar application of micronutrients (Table. 3 and Fig 1,2 and 3). However, the decrease in available nutrients in soil with micronutrients application might be attributed to higher bulb yield of onion and higher uptake of these nutrients from the soil. This result was confirmed with the result found by Babaleshwar et al., 2017.

\section{Nutrient uptake}

The total uptake of major nutrients $(\mathrm{N}, \mathrm{P}, \mathrm{K})$ observed significantly highest with application of $\mathrm{B}$ and $\mathrm{Zn}$ along with STBFR $(141.45 \mathrm{~kg} / \mathrm{ha}, 11.27 \mathrm{~kg} / \mathrm{ha}, 112.00 \mathrm{~kg} / \mathrm{ha} \mathrm{N}$, $\mathrm{P}, \mathrm{K}$ respectively) followed by the treatment applied with STBFR+ Soil application of Zinc @ $2.5 \mathrm{~kg} / \mathrm{ha}+$ Foliar spray of ZnSO4@0.5\% two times $30 \& 45$ DAP $(136.37 \mathrm{~kg} / \mathrm{ha}, 10.50$ $\mathrm{kg} / \mathrm{ha}, 105.77 \mathrm{~kg} / \mathrm{ha} \mathrm{N}, \mathrm{P}, \mathrm{K}$ respectively).

Table.1 Effect of Zinc and Boron on Yield and Yield attributing characters

\begin{tabular}{|l|l|l|l|l|l|l|}
\hline Treatments & $\begin{array}{c}\text { Plant } \\
\text { height } \\
(\mathbf{c m})\end{array}$ & $\begin{array}{c}\text { Bulb } \\
\text { Diameter } \\
(\mathbf{c m})\end{array}$ & $\begin{array}{c}\text { Bulb } \\
\text { weight } \\
(\mathbf{g})\end{array}$ & TSS (\%) & $\begin{array}{c}\text { Yield } \\
(\mathbf{q} / \mathbf{h a})\end{array}$ & $\begin{array}{l}\text { \% } \\
\text { Increase } \\
\text { in Yield }\end{array}$ \\
\hline T1 & 41.51 & 4.27 & 53.90 & 9.72 & 180.50 & - \\
\hline T2 & 44.37 & 5.98 & 57.80 & 10.95 & 210.25 & 16.48 \\
\hline T3 & 47.40 & 6.08 & 59.75 & 12.14 & 220.25 & 22.02 \\
\hline T4 & 49.17 & 6.11 & 64.82 & 12.57 & 229.00 & 26.86 \\
\hline T5 & 50.64 & 6.19 & 69.20 & 13.10 & 234.50 & 29.91 \\
\hline T6 & 52.89 & 6.79 & 72.57 & 13.57 & 243.00 & 34.62 \\
\hline Sem & 0.32 & 0.05 & 0.66 & 0.18 & 2.68 & - \\
\hline CD 5\% & 0.95 & 0.15 & 1.98 & 0.55 & 8.1 & - \\
\hline
\end{tabular}


Table.2 Effect of Zinc and Boron on Available NPK content in Bulb

\begin{tabular}{|c|c|c|c|}
\hline Treatments & \% N content & \% P content & \% K content \\
\hline T1 & 1.14 & 0.14 & 0.78 \\
\hline T2 & 1.23 & 0.24 & 1.18 \\
\hline T3 & 1.35 & 0.32 & 1.33 \\
\hline T4 & 1.41 & 0.36 & 1.43 \\
\hline T5 & 1.49 & 0.43 & 1.51 \\
\hline T6 & 1.58 & 0.51 & 1.59 \\
\hline Sem & 0.01 & 0.01 & 0.03 \\
\hline CD 5\% & 0.04 & 0.04 & 0.08 \\
\hline
\end{tabular}

Table.3 Effect of Zinc and Boron on Post-harvest NPK content of Soil

\begin{tabular}{|c|c|c|c|}
\hline Treatments & Soil N kg/ha & Soil P kg/ha & Soil K kg /ha \\
\hline T1 & 242.88 & 15.15 & 188.65 \\
\hline T2 & 220.93 & 12.25 & 175.10 \\
\hline T3 & 223.20 & 12.97 & 179.90 \\
\hline T4 & 228.23 & 13.37 & 181.97 \\
\hline T5 & 235.45 & 14.40 & 184.10 \\
\hline T6 & 216.03 & 11.13 & 167.60 \\
\hline Sem & 1.38 & 0.19 & 0.94 \\
\hline CD 5\% & 4.16 & 0.58 & 2.83 \\
\hline
\end{tabular}

Table.4 Effect of Zinc and Boron on Uptake of Nutrients

\begin{tabular}{|c|c|c|c|}
\hline Treatments & Available N kg/ha & Available P kg/ha & Available K kg /ha \\
\hline T1 & 115.85 & 7.65 & 77.05 \\
\hline T2 & 121.65 & 8.87 & 86.75 \\
\hline T3 & 126.32 & 9.37 & 93.07 \\
\hline T4 & 131.90 & 9.87 & 99.42 \\
\hline T5 & 136.37 & 10.50 & 105.77 \\
\hline T6 & 141.45 & 11.27 & 112.00 \\
\hline Sem & 1.06 & 0.18 & 1.34 \\
\hline CD 5\% & 3.21 & 0.54 & 4.05 \\
\hline
\end{tabular}


Int.J.Curr.Microbiol.App.Sci (2020) 9(6): 1403-1412

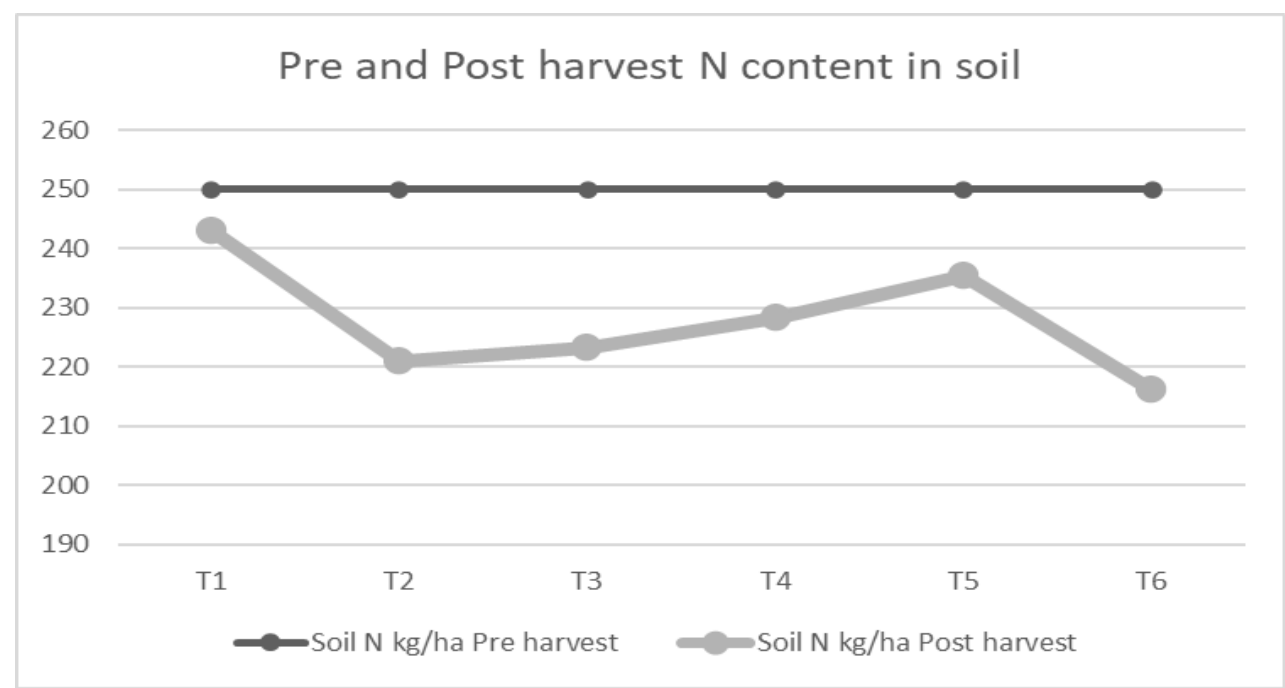

Fig.1

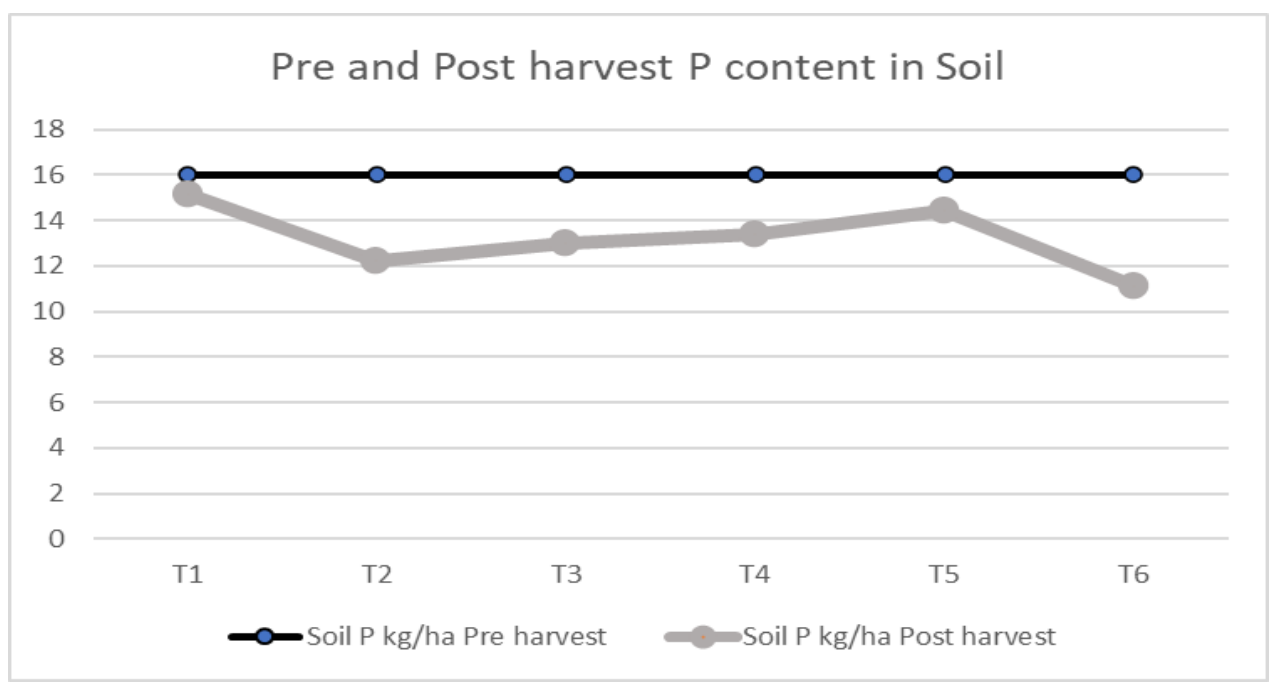

Fig.2

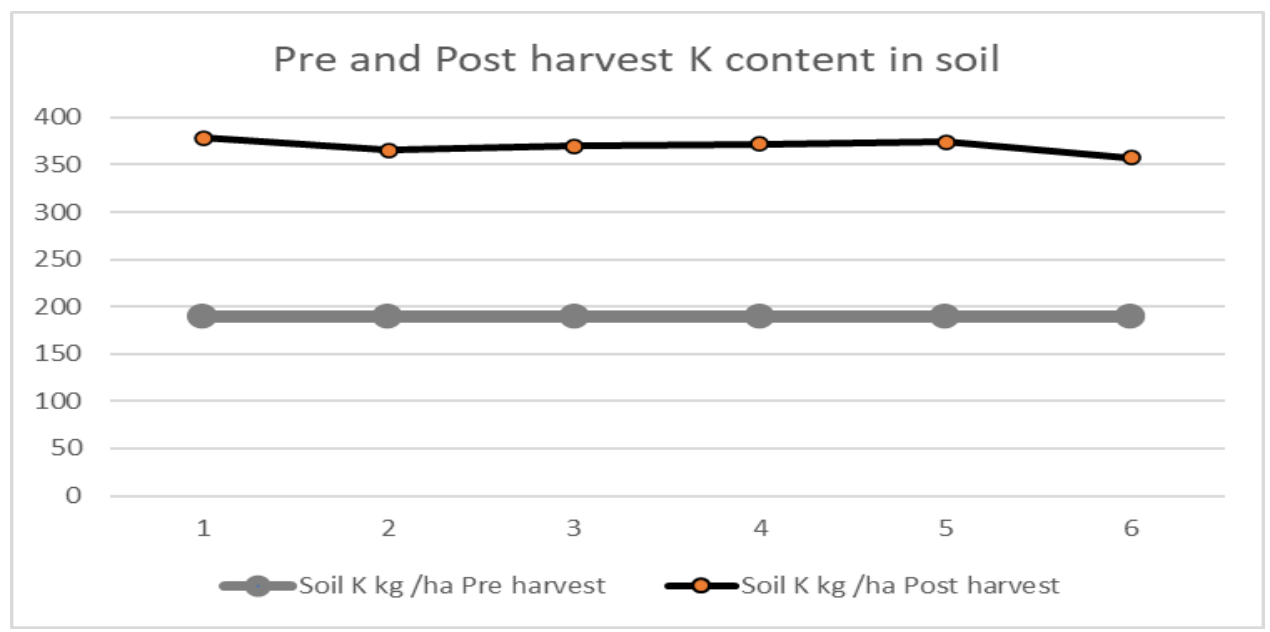

Fig.3 
However, the lowest uptake of NPK by bulb $(115.85 \mathrm{~kg} / \mathrm{ha}, 7.65 \mathrm{~kg} / \mathrm{ha}$ and $77.05 \mathrm{~kg} / \mathrm{ha}$ of NPK respectively) was observed in $T_{1}$ treatment that received zero application of $\mathrm{B}$ and $\mathrm{Zn}$. These findings corroborate with the results reported by Singh and Pandey (2006) and Rathod et al., (2020) and Begum et al., 2015. Pallavi et al., (2015) reported higher uptake of nutrients with increased levels micronutrients. However, significant increases in uptake in bulb onion due to the foliar application of micronutrients confirm that fertilizers are absorbed right at the site where they are used and are effective sources of traits and better nutrient uptake by onion bulb under foliar fertilization than soil application (Fouda, 2017).

From the present study it was concluded that application of micronutrients like Boron and Zinc to onion crop have significant impact on production of better bulb quality in terms of TSS and also provided better yield Among all the treatment schedule, it was observed that the treatment schedule, $\mathrm{T}_{6}$ i.e., STBFR+ Soil application of Boron @ 1 kg/ha \&Zinc @ 5 $\mathrm{kg} / \mathrm{ha}$ significantly recorded better results on almost all parameters under study than rest of the treatments.

\section{References}

Acharya U, Venkatesan K, Saraswathi T, Subramanian KS. 2015.Effect of zinc and boron application on growth and yield parameters of multiplier onion (Allium cepaL. var. aggregatum Don.) var. CO-5. International Journal of Research (IJR), 2(1):757-765.

Alam MN, Abedin MJ, Azad MK. Effect of micronutrients on growth and yield of onion under calcareous soil environment. Int. Res. J Plt. Sci. 2010; 1(3):56-61.

Anon. Horticultural statistics at a glance 2017.Govt. of India, ministry of agriculture and farmers welfare. Department of agriculture, cooperation and farmers welfare horticulture statistics division, 2017.

Aske Vijay, Jain PK, Lal N, Shiurkar G. Effect of Micronutrients on Yield, Quality and Storability of Onion cv. Bhima Super. Trends in Biosciences. 2017; 10(6):1354-1358.

Babaleshwar, S B., Shilpa R. Koppad, P. R. Dharmatti and K. K. Math,2017. Impact of Micronutrients on Growth, Yield and Quality of Onion (Allium cepa) International Journal of Pure and Applied Bioscience. 5 (6): 1205-1209

Ballabh K and DK Rana.2012.Response of micronutrients on qualitative and quantitative parameters of onion (Allium cepa L.). Progressive Horticulture; 44(1):40-46.

Ballabh K, Rana DK and Rawat SS. 2013.Effects of foliar application of micronutrients on growth, yield and quality of onion. Indian J. Hort., 70(2):260-265.

Begum R, Jahiruddin M, Kader MA ,Haque MA and Hoque ABMA. 2015. Effect of zinc and boron applicationon onion and their residual effects on Mungbean, Progressive Agriculture, 26: 90-96.

Chopra S.L and Kanwar J.S.1978.Analytical Agricultural Chemistry, Kalyani Publisher, Ludiana

Fouda K F. 2017. Response of Onion Yield and Its Chemical Content to NPK Fertilization andFoliar Application of Some Micronutrients. Egypt. J. Soil Sci. pp.1-12.

Gamelli, E. L., Hanna, N. and Hadi, E. L. 2000.The effect of some foliar fertilizers application on growth, bulb yield, quality and storage ability of onion. Journal of Horticulture 12: 3038.

Gomez, K.A. and Gomez, A.A. (1984).Statistical Procedures for 
Agricultural Re-search (2nd Ed). John Wiley \& Sons, New York. pp. 28-192.

Hansch R, Mendel RR.2009. Physiological functions of mineral micronutrients $(\mathrm{Cr}$, $\mathrm{Zn}, \mathrm{Mn}, \mathrm{Fe}, \mathrm{Ni}, \mathrm{Mo}, \mathrm{B}, \mathrm{Cl})$. Curr.Opin. Plant Biol., 12:259-66.

Jackson, M.L., 1973. Soil Chemical Analysis (Edn. 2) Prentice Hall of India Pvt Ltd New Delhi. 69-182.

Khan, A.A., Zubair, M., Bari, A. and Maula, F.2007. Response of onion (Allium cepa) growth and yield to different levels of nitrogen and zinc in swat valley. Sarh. J. of Agric., 23: 933-936.

Lal S, Maurya AN. Effect of zinc on onion. Haryana Journal of Horticulture Science. 1981; 10(3-4):231-235.

Manna D, Maity TK.2016.Growth, yield and bulb quality of onion (Allium cepa L.) in response to foliar application of boron and zinc.Journal of Plant Nutrition. 2016; 39(3):438-441.

Manna, D.2013.Growth, yield and bulb quality of onion (Allium cepa L.) in response to foliar application of boron and zinc. SAARC J. Agri., 11(1): 149153 (2013).

PallaviGhotekar, Katkar, R.N., Kharche, V.K., Laharia, G.S., Ghawade, S.M. and Lakhe, S.R. 2015.Effect of sources and levels of sulphur on yield and quality of onion and soil fertility status. Journal of Agriculture Research and Technology, 40 (1): 163-166.

Patil BC, Hosamani RM, Ajjappalavara PS, Naik BH, Smitha RP, Ukkund KC. 2008. Effect of foliar application of micronutrients on growth and yield components of tomato (Lycopersicon esculentum Mill.). Karnataka J. Agric. Sci. 2008; 21(3):428-430.

Patil, V.K., Yadlod, S.S., Tambe, T.B. and Narsude, P.B. 2009. Effect of foliar application of micronutrients on flowering and fruit set of tomato (Lycopersicon esculentum Mill. cv.
Phule Raja). International Journal of Agricultural Sciences 6(1): 164-166.

Phor, S.K., Pandey, U.C. and Verma, U. 1995. Effects of zinc on the growth and yield of garlic (Allium sativum L). Crop Research 9: 286-291.

Pramanik K., P Tripathy, P Mandal, M Pradhan and M Biswal (2018). Effect of micronutrients on quality of onion (Allium cepa L.) International Journal of Chemical Studies; 6(6): 1324-1327

Rathod P.H., R.N. Katkar, R. Vrushali. Bhende S.M. Ghawade, S.R. Lakhe, and Kharche.V.K. 2020. Effect of Sulphur and Zinc Containing Customized Fertilizers on Growth, Yield and Nutrient Uptake of Onion. Int.J.Curr.Microbiol.App.Sci. $\quad 9(01)$ : 2061-2069.

doi: https://doi.org/10.20546/ijcmas.2020.90 1.234

Singh V. and M. Pandey. 2006. Effect of integrated nutrient management on yield of and nutrient uptake by onion and on soil fertility. J. Indian Soc. Soil Sci. 54(3): 365-367.

Singh, D.P. and Tiwari.R.S. 1996.Effect of micro-nutrients on yield and quality of Onion (Allium cepa L) variety Pusa Red. Recent Horticulture 3:111-117.

Smriti, S., Kumar, R. and Singh, S. K. 2002. Effect of Sulphur and Boron nutrition on growth, yield and quality of onion. Journal of Applied Biology 12: 40-46.

Tariq A. Bhat1, M.A. Chattoo, F. Mushtaq, F. Akhter, S.A. Mir, M.Y. Zargar, K.P Wani, M.D. Shah and Ejaz, A. Parry, 2018. Effect of Zinc and Boron on Growth and Yield of Onion under Temperate Conditions Int.J.Curr. Microbiol.App.Sci (2018) 7(4): 37763783.

Tisdale, S. L., Nelson, W. L. and Beaten, J. D. 1984. Zinc. Soil Fertility and Fertilizers. Macmillan Publishing Company, New York. Fourth Edition pp. 382-391. 
Tiwari, R.S., Ankur, A. and Sengar, S.C. 2003.Effect of bioregulators on growth, bulb yield, quality and storability of onion cv.Pusa Red. Indian Journal of Plant Physiology 8(4):411-413.

Trivedi AP, Dhumal KN. 2013. Effect of soil and foliar applications of zinc and iron on the yield and quality of onion (Allium cepa L.). Bangladesh Journal of Agricultural Research, 38(1):41-48.

Verma, S. K., Singh, S. S. and Awasthi, C. P. 1995.Response of zinc and boron fertilization on yield and quality fruits at different stages of picking. Vegetable Science 22: 5-8.

Vitosh, M. L. Warncke D. D. and Lucas, R. E. 2001.Secondary and micronutrients for vegetables and field crops. Crop and Soil Sciences 5: 18-36.

Waqar, A., Niaz, A., S. Kanwal, R. and Khalid, R.2009. Role of boron in plant growth. Journal of Agriculture Research 2: 47-52.

\section{How to cite this article:}

Prusty. M., N. Mishra, S. Samal and Kar. D. S. 2020. Effect of Zinc and Boron on Growth, Yield, Bulb quality and Nutrient uptake of Onion (Allium cepa L.) cv Bhima Super under MidCentral Table Land Zone of Odisha, India. Int.J.Curr.Microbiol.App.Sci. 9(06): 1403-1412. doi: https://doi.org/10.20546/ijcmas.2020.906.175 